\title{
Da tutela ao contrato: "homens de cor" brasileiros e o movimento operário carioca no pós-abolição*
}

\author{
Maria Cecília Velasco e Cruz
}

Ao estudarem o surgimento dos movimentos operário e sindical brasileiros os cientistas sociais e os historiadores partiram inicialmente da ideia de que a formação da classe operária no Brasil e a imigração europeia eram processos sociais necessariamente imbricados. Esta suposição, logo tomada como fato inquestionável, direcionou a pesquisa histórica para o Centro-Sul, e mais especificamente para São Paulo, ${ }^{1}$ com a consequente supervalorização do universo fabril e dos imigrantes estrangeiros, e a minimização do papel desempenhado pelos brasileiros na organização da classe trabalhadora, tanto na fábrica como fora dela. Os operários nacionais brancos, negros ou pardos foram vistos como abertos a práticas paternalistas ou clientelistas, mais passivos, moderados, e pouco inclinados a seguir o slogan de que a emancipação operária era obra dos próprios trabalhadores. ${ }^{2}$

Deste modo, apesar da descoberta de que, diferentemente de Santos, havia no porto do Rio de Janeiro sindicatos de maioria negra solidamente organizados, os historiadores pouco avançaram na análise do fenômeno. As organizações dos marítimos, dos estivadores e dos carregadores ou foram vistas como exceções, volta e meia mencionadas, mas nunca estudadas de forma detalhada, ${ }^{3}$ ou foram englobadas em investigações mais gerais sobre o reformismo sindical carioca, o que apagava as especificidades do sindicalismo portuário, e obscurecia a participação dos "homens de cor" no movimento operário da cidade. ${ }^{4}$ A supervalorização dos imigrantes na formação dos sindicatos da Primeira República, implícita nesse descaso pelo estudo aprofundado dos sindicatos cariocas de maioria negra ou parda, pode ser também uma das razões pelas quais até hoje pouco se sabe sobre os primórdios do movimento sindical em estados como Pernambuco, Ceará ou Amazonas que, embora tenham tido imprensa e organizaçôes operárias ativas desde o início do século XX, representam verdadeiros vazios historiográficos na literatura especializada sobre o tema.

Em certo sentido, e de forma mais ou menos nuançada, nos estudos sobre o movimento operário das décadas posteriores à Abolição, prevaleceu por um bom tempo a imagem da anomia, da marginalidade e do despreparo dos ex-escravos para o trabalho autônomo na ordem capitalista competitiva, esboçada nas análises sociológicas de Fernandes. ${ }^{5}$ Com isso, a história social dos escravos e a da classe operária brasileira foram concebidas como campos historiográficos distintos e apartados, pois seus objetos eram realidades sem comunicação. ${ }^{6}$

Este não é mais o estado da arte, é claro. Todos concordam que a suposição que estruturou inicialmente o campo de estudos sobre a formação dos movimentos operário e sindical brasileiros não tem sustentação empírica e é teoricamente falha. Todos estão de acordo, também, sobre a necessidade de se transpor o abismo que separava as investigações sobre a escravidão e a classe trabalhadora livre no Brasil. Diz-se "separava", porque avanços foram feitos e já se percebeu que essas histórias são em muitos aspectos emaranhadas. ${ }^{7}$ No entanto, apesar desses avanços - e eles foram significativos - os elos que interligam os mundos dos trabalhadores no fim do século XIX e no século XX continuam a nos escapar e nos desafiar. É sobre isso que se deseja refletir.

As considerações de Marcus Carvalho sobre a noção de liberdade e as concepções culturais dos escravos africanos servirão como porta de entrada ao tema central deste artigo. Demonstrar por que, para se construir uma ponte que nos leve a uma compreensão mais sólida da participação dos libertos e

\footnotetext{
* Agradeço os comentários de Beatriz Ana Loner, João José Reis, Sebastião Velasco e Cruz, Evergton Sales Souza e dos membros da linha de pesquisa "Escravidão e invenção da liberdade" do Programa de Pós-Graduação em História da Universidade Federal da Bahia (UFBA).
} 
dos seus descendentes na formação do movimento operário da Primeira República, é preciso ir além dos estudos que privilegiam as experiências individuais e o agir humano (agency) sem buscar inseri-los em análises estruturais do mercado de trabalho, das relações de produção e dos processos de trabalho. Esta abordagem metodológica, presente em boa parte da historiografia contemporânea, dificulta o estabelecimento das conexões buscadas por razões que se quer examinar. Para tanto, constrói-se o argumento a partir de uma análise substantiva, cujos fios condutores são a elucidação de "termos de época", e a discussão dos significados do conceito de liberdade implícitos nas falas dos patróes e operários em dois momentos distintos - as greves feitas para consolidar a Sociedade de Resistência dos Trabalhadores em Trapiche e Café, em 1906; e o movimento antissindical desencadeado pelo patronato contra a Sociedade de Resistência, em 1917-1918.

Segundo Carvalho, "no dia a dia, é comum empregar-se a palavra liberdade como se fosse um termo autoevidente, desligado da experiência histórica das pessoas. [...] É como se a liberdade fosse um dado absoluto, que existe ou não, de forma claramente delimitada". Todavia, como bem notou Moses Finley "a liberdade não é um termo simples, que dispensa maiores explicações. Ao contrário, ela deve ser entendida de uma forma dialética, ou seja, em oposição à noção de não-liberdade. Não se trata, portanto, de um conceito estático, mas um 'terreno de conflito', na feliz expressão de Eric Foner”. Concordando com essas proposições Carvalho conclui que a situação de ser ou não ser livre deve ser analisada dentro de um contexto histórico concreto. "A liberdade é um processo de conquistas, que podem ou não ser alcançadas durante o correr de uma vida. [...] É um caminho a ser percorrido, e não uma situação estática e definitiva". ${ }^{8}$

É fácil ver que essas reflexões entrelaçam dois planos analíticos distintos. Um é de natureza simbólica - a liberdade é um valor e um conceito definidos por oposição ao que se entende e se valora como o seu contrário, a não-liberdade. O outro plano é de natureza concreta - a liberdade é uma dimensão dinâmica da vida social. Ser ou não ser livre é uma porta que se abre ou que se fecha, uma barreira que se ergue ou se transpõe. Ambos os planos são, por outro lado, "terrenos de conflito" contextuais e históricos. A liberdade não tem um sentido único, ontológico. Seus significados são múltiplos e entrelaçados a jogos de linguagem, disputas, açōes e reações individuais ou coletivas de homens e mulheres específicos.

Por isso o alerta: "se não for devidamente contextualizada no tempo, a liberdade corre o risco de tornar-se... uma abstração de uma condição do presente, imposta sobre o passado". ${ }^{9}$ E a consequente afirmação: é errôneo pensar que o escravo africano que "se mandou pro mato", fugiu para a liberdade. O historiador que assim pensasse estaria cometendo um anacronismo: "assumir que a liberdade perseguida pelo quilombola era a mesma do mundo burguês, equacionada com a ideia de autonomia individual, como se somente isso bastasse". Para agir de acordo com sua experiência e sua cultura "era preciso que o fugitivo passasse a pertencer a uma comunidade alternativa: o quilombo". ${ }^{10}$

Este fato, isto é, a conexão entre a busca de "pertencimento" e a ideia de liberdade, é um dado plenamente incorporado pela nova historiografia da escravidão. O estudo de Carvalho é apenas um exemplo entre muitos outros. São inúmeros os trabalhos que reconstituem com sensibilidade as múltiplas formas de elaboração desse "pertencimento": a recriação ou invenção de laços étnicos; o estabelecimento de redes de relações comunitárias e familiares; a preservação e reconfiguração de formas de associação religiosa e cultural, inclusive formas de "folgar" e "brincar". É na construção desse "pertencimento" que os escravos começam a neutralizar a morte social provocada pela sua captura original e venda, como também a dar os primeiros passos em direção à liberdade. Aí se enraízam inúmeras formas de resistência cotidiana ao cativeiro.

Apesar do seu papel fundamental para o entendimento das práticas sociais dos cativos, a noção de "pertencimento" não é, evidentemente, a varinha de condão que resolve todos os enigmas e significados 
da noção de liberdade dos escravos. Voltaremos a esse tema adiante. Agora, cabe indagar, e os operários? Será que podemos supor que sua concepção de liberdade é a burguesa, só porque estamos estudando o século XX, mais de cem anos depois que as ideias iluministas revolucionaram o mundo, derrubaram privilégios, difundiram os valores da igualdade perante a lei, e subverteram o sentido das relações sociais? Será que ter o direito de ir e vir, escolher onde morar, dizer o que se pensa, trabalhar para quem quiser, comprar e vender, e consumir o desejado dentro dos limites do possível - é o bastante para que os operários das primeiras décadas republicanas sintam-se "livres"? E se estes operários forem libertos, ou filhos de libertos? Será que este fato interfere nas suas noções de liberdade ou sujeição? E se interfere, qual é esta interferência? Como detectá-la nas fontes históricas, nesses vestígios fragmentados a partir dos quais compomos nossas narrativas? Um anúncio patronal publicado em 1918, durante um duro confronto trabalhista, permitirá que se comece a responder essas questóes.

Ele diz o seguinte: "Trabalhadores Livres. Admite-se para o serviço de café. Trata-se no respectivo Centro, à Rua da Quitanda, 191". A estes dizeres, segue-se uma tabela de preços para as tarefas relativas aos "lotes" e aos "embarques", bem como os horários para os serviços de máquinas. ${ }^{11}$ Este anúncio é uma boa indicação de que também no mundo capitalista das primeiras décadas do século XX, apesar da crescente hegemonia dos valores liberais, a liberdade continua a ser um terreno de conflito. Nas assembleias patronais, a tônica são as discussões sobre o "trabalho livre", chegando-se depois a essa tabela de preços para os "trabalhadores livres" - os únicos que os patrões aceitariam em seus armazéns. Quem são esses "trabalhadores livres" que o Centro procura contratar? Que noção de liberdade é esta?

O patronato concebe a liberdade como "liberdade de contrato". A seu ver, por suposto, como no "mercado" encontram-se pessoas juridicamente "livres e iguais", elas celebram contratos, trocando "mercadorias" sem sofrer pressões. De um lado, o operário "livre" oferece a sua capacidade física e mental para produzir. Do outro, o patrão, dono dos meios de produção, oferece o dinheiro (sua "mercadoria") para comprar a "mercadoria" do operário, ou seja, a sua força de trabalho. Todos são "proprietários" porque desde a difusão dos escritos de Locke o trabalho passa a ser concebido cada vez mais como uma "propriedade" dos indivíduos. Ora, como todos são "autônomos e livres", as trocas mercantis se fazem sem coações. O mercado é, portanto, o "reino da liberdade". Todavia, se isso é verdade, o sindicato é uma aberração, porque fere a "liberdade de contrato" e, assim, a "livre" busca dos interesses materiais individuais.

É esta concepção de liberdade que orienta as ações do patronato. Os patrões querem negociar com "trabalhadores livres", isto é, trabalhadores por eles "libertados" do "jugo" do sindicato. Trabalhadores livres são trabalhadores desorganizados. São estes indivíduos que buscam empregar. Porém, não é esta a noção de liberdade que aparece nos manifestos espalhados pelas ruas em dezembro de 1906, quando os operários lutam para consolidar a Sociedade de Resistência dos Trabalhadores em Trapiche e Café, organização sindical envolvida nas disputas que provocam o referido anúncio patronal. Em um desses manifestos os operários escrevem:

Companheiros, alerta!... ainda estamos em greve. Existem diversos trapiches que de forma alguma querem assinar o contrato com esta Associação. E por quê? É por falta da verdadeira união, que tem sido tão desigual quão prejudicial para todos nós que almejamos o direito e a nossa liberdade. [...] Avante! Vamos concluir o nosso direito, que... muito breve teremos a nossa completa liberdade. ${ }^{12}$

A simples leitura desse trecho já demonstra que a noção de liberdade dos operários não é a dos patrōes, pois é fruto de um contrato assinado com a Associação. Contudo, a divergência de posiçōes aparece mais claramente ainda em outros materiais históricos surgidos em meio a esta longa disputa, que iniciada em 1917, cresce e se radicaliza até unir diversas associaçôes patronais numa verdadeira cruzada antissindical. Um exemplo é a discussão travada numa reunião de negociação entre patrōes e operários, transcrita no Jornal do Brasil e também no relatório do Centro de Comércio e Indústria - um documento patronal reservado. As palavras são praticamente as mesmas, o que permite supor que o sentido dos diálogos não foi muito alterado. Abaixo, algumas passagens da discussão: 
Dada a palavra ao Sr. José Joaquim de Brito [representante dos proprietários de carroças], este diz que só pode discutir a questão dos preços.

- O Sr. Francisco Leal [presidente da Associação Comercial] diz: - esta questão nós não discutimos... porque diz respeito à oferta e à procura. Cada um deve pedir o preço que lhe convém e aquele que pede o trabalho, a ele se sujeita ou não. [...]

Dada a palavra ao Sr. Raphael Muñoz [representante da Resistência], este salienta que a luta é entre o capital e o trabalho, a qual é antiga. Atualmente o que se estabeleceu foi a discórdia promovida por um grupo, em detrimento de um costume aceito sem recriminaçóes [...] É preciso notar que a Resistência estava cobrando... os preços de $1907 \ldots$

- O Sr. Narcizo Braga [comerciante]: - Repetimos, não é a questão dos preços que nos preocupa, mas a necessidade de libertarmos o trabalho [...]

- O Sr. Muñoz - Que é a liberdade de trabalho?

- O Sr. Leal - É o direito que cada um de nós tem de mandar fazer o serviço por quem nos ofereça maiores garantias e preços menores.

- O Sr. Muñoz - Os senhores podem escolher os operários, mas estes não podem escolher os patrões porque têm necessidade deles, logo não há liberdade de trabalho, e onde há necessidade não há liberdade. ${ }^{13}$

Nada mais claro. Para muitos operários, o mercado não é visto como um "reino da liberdade". Não há "liberdade de contrato" porque as partes contratantes não possuem a igualdade pressuposta pelos patrões. A relação entre capital e trabalho é uma relação desigual, porque os trabalhadores, não tendo outro meio de sobrevivência, são forçados a vender sua força de trabalho nas condiçõos que lhes são propostas. Ao contrário do que postula a ideologia liberal, os trabalhadores, na prática, não têm o direito de escolher o patrão. Este sim tem o direito de escolher os trabalhadores, pois como afirma a Resistência em outros documentos - eles (os patrôes) podem empregar seus capitais onde bem quiserem.

Em suma, os patrôes fazem um uso extremado do conceito negativo de liberdade - liberdade como ausência de obstáculos ao livre curso das escolhas individuais. Os operários agem baseados num conceito positivo de liberdade - liberdade como construção coletiva de autonomia, como predicado de indivíduos que, agrupados, convertem-se em sujeitos de escolhas, deixando de ser simples objetos das escolhas alheias. ${ }^{14}$

Sim - o leitor atento já deve estar pensando - no mundo burguês não é complicado notar que a liberdade é um alvo privilegiado de lutas. Mas os embates aludidos acima são disputas que afetam todos os operários, inclusive os imigrantes brancos. E o liberto, ou seu filho? Em que sua bagagem sociocultural interfere e marca a dinâmica do conflito? Onde estão as conexões entre os estudos sobre a escravidão e os trabalhos sobre o movimento operário? Será que na base desse conceito positivo de liberdade existem valores que se enraízam nas experiências do cativeiro?

Ao final deste mesmo conflito, em agosto de 1918, um operário idoso revela a um repórter que antes da Sociedade de Resistência

...o nosso senhor era o "capitão" da tropa. Um capitão arranjava os trabalhadores e, por isso, recebia $4 \%$ da importância paga, mais 400 réis por cabeça e os "quebrados". [...] Os quebrados... eram: 60 réis de um, 80 réis de outro... O trabalhador ganhava $5 \$ 980$. Os 80 réis “morriam”. A Resistência acabou com isso. O dinheiro é repartido irmamente por todos. E dá-se, então, este fenômeno...: como todos concordam com isso, e nenhum prejudica o outro,...? É que nós... constituímos uma família.

A Resistência fez mais ainda: acabou com a "escravidão do trabalhador". Antes [...] era comum ser um carregador surrado com chicote de barbante. Não havia apelação... "malhavam o negro”... e a polícia de nada sabia. [...] essa situação, se para alguns era natural, porque a sua infeliz condição de trabalhador de café era um prolongamento do eito, que o 13 de Maio demoliu, para a maioria era uma afronta... E Deus inspirou... esse punhado de... companheiros que levantaram a Resistência... A Resistência deu o grito do novo 13 de Maio. ${ }^{15}$

Aí estão as conexões. Algumas, como esta referência direta à Abolição, são quase autoevidentes, principalmente se já soubermos que os trabalhadores organizados na Resistência são majoritariamente "homens de cor", como já demonstrado em outro lugar. ${ }^{16}$ No Brasil das primeiras décadas republicanas, menções à "escravidão moderna" são comuns no discurso dos militantes sindicais, numa crítica dura à 
sociedade industrial. Mas, apesar das alterações de palavras certamente feitas pelo jornalista, é fácil ver que o velho carregador não se refere à fábrica. Na sua fala emerge um fragmento do cotidiano que projeta as experiências amargas do cativeiro diretamente na vida dos operários. Dizer que a Resistência dera "o grito do novo 13 de Maio" é expressar um simbolismo pleno de significado, pois construído sobre conexões reais entre os escravos, rituais de subordinação ainda inspirados em práticas escravistas e os trabalhadores de trapiche e café do Rio de Janeiro republicano.

A maioria das conexões não é, todavia, assim tão óbvia. Referências explícitas à Abolição, ou reivindicações significativas como a dos foguistas cariocas que, em 1906, entram em greve e exigem o fim das refeições nas "vexaminosas bandejas" por "lembrar[em] o Brasil da escravidão", não surgem com frequência em nossas fontes. Pelo contrário, nelas a maior parte das referências ao passado é cifrada. Deste modo, cabe indagar: quem é o "capitão de tropa"? Por que o idoso diz que antes da Resistência o capitão "era o nosso senhor"? Por que Muñoz, ao falar da luta entre capital e trabalho, afirma que ela é "antiga”, mas que a discórdia "atualmente" é "em detrimento de um costume aceito sem recriminações"? Que costume é esse ao qual ele se refere sem maiores explicaçōes? E por que, durante este conflito, as queixas recorrentes dos patrōes são contra os "fiscais"?

São falas e expressões como essas, a princípio enigmáticas, que sinalizam na maioria das vezes as dificuldades e o sentido do percurso. Mas, como sempre, para se converterem em apoios os sinais precisam ser entendidos. Sendo mais clara, para que as expressóes acima mencionadas balizem caminhos interpretativos é preciso descobrir, mediante uma análise estrutural das relações de produção e do mercado de trabalho, que nas primeiras décadas republicanas há uma superposição de categorias na linguagem dos sócios da Resistência. "Capitão", "representante do trabalho" e "encarregado do trabalho" são termos que designam indistintamente indivíduos que desempenham uma função inúmeras vezes descrita pelos viajantes do século XIX, ao se reportarem aos líderes surgidos da dinâmica interna dos grupos urbanos de escravos ganhadores do Rio de Janeiro - a de fazer a intermediação entre os comerciantes e os trabalhadores avulsos ${ }^{17}$ arregimentados para movimentar café e outras mercadorias na região portuária. ${ }^{18}$

Além disso, é necessário desvendar também que as expressōes "trabalhadores de tropa", e por extensão "capitão de tropa", são analogias que têm um sentido preciso no linguajar carioca da época. Até meados do século XIX, a maior parte das sacas de café exportadas pelo porto do Rio de Janeiro desce em lombo de burro das fazendas do planalto cafeeiro para um entreposto no litoral, convergindo para a Corte por via marítima. Os animais de carga que penetram na zona urbana são conduzidos pelo meio das ruas, presos uns atrás dos outros, e nesta mesma ordem descarregam e aguardam carregamentos de retorno na Praia dos Mineiros, no Largo de São Francisco e no Campo de Santana. ${ }^{19}$ Toda a movimentação das sacas de café entre os trapiches e as casas comissárias, entre estas e os armazéns dos ensacadores, ou entre estes e o Consulado é feita, no entanto, por "magotes de negros enfileirados, sacaria à cabeça", que por analogia com as bestas de carga passam a ser conhecidos "como trabalhadores de tropa". ${ }^{20}$

O momento preciso em que a expressão generaliza-se é difícil de ser datado, mas parte do processo é evidente. Em meados do Oitocentos, esses ajuntamentos de negros, quase todos africanos, já constituem uma fração de classe percebida na força de trabalho, pois desde 1853 seus passos são regulados por uma postura municipal exclusiva. Quando "os magotes de pretos carregadores de café" saírem carregados "dos armazéns da Rua Nova de São Bento e suas imediações... em direção ao Consulado, devem descer sempre pelo lado direito das ruas... deixando livre o passeio lajeado", e quando voltarem para buscar "novas cargas, seguem pelo lado esquerdo, e também fora do passeio", com multa de quatro mil réis para os infratores ${ }^{21}$. Os "capitães de tropas" são, por conseguinte, originalmente, apenas os capitães que comandam as turmas de "pretos" enfileirados, ou "tropas"do café. Não obstante, com o passar do tempo, a metáfora sofre uma expansão semântica e começa a ser empregada para denominar também os trabalhadores avulsos que transportam, à cabeça e em grupos, diferentes tipos de carga. É esse uso mais amplo da expressão, mas ainda assim restrito a um determinado conjunto de operários, que aparece nas fontes históricas do início do século XX. 
É que apesar da substituição das turmas de negros pelas carroças nos trajetos longos, esses agrupamentos humanos não desaparecem do mercado de trabalho. Como a oferta de emprego é múltipla e dispersa por todo o sistema portuário, os capitães e suas "tropas" começam a se fixar junto às casas de café e trapiches, numa apropriação de territórios que visa demarcar fronteiras, estabelecer reservas de mercado, e se tornar, enfim, conhecido e requerido pelo "outro". No alvorecer da República, relações sociais costumeiras prendem os "trabalhadores de tropa" perto dos diversos pontos de trabalho do porto, mas principalmente junto às casas de café, onde estão em suas mãos, tanto as tarefas de preparação dos grãos para exportação (repasse do café em máquinas, ensacamento, pesagem e empilhamento dos sacos em lotes de número e peso uniformes), como o transporte à cabeça da sacaria, ou sua arrumação nas carroças. Pois bem, apesar da enorme quantidade de imigrantes que embranquece a paisagem urbana, a maioria desses homens continua sendo negra, como a observação atenta de dois viajantes consegue distinguir em meio à babel de nacionalidades e cores existente nas ruas adjacentes ao porto. "O carro que me transporta”, escreve João Chagas em 1897:

...é uma espécie de velha caleche com um largo postigo aberto, por onde vou lançando um olhar aos lugares que percorro. [...] São primeiro ruas estreitas, escuras, entre casas velhas... habitadas provavelmente por gente do comércio, porque não vejo portas de escada, mas unicamente lojas e armazéns... e, nos umbrais de pedra, nomes de firmas, inscritas umas após outras [...] a caleche corre... por travessas e vielas entre uma população atarefada de carregadores, moços de frete,... vendedores, compradores, negros, brancos, mulatos, cruzando-se em todas as direções, entrando aqui, saindo acolá... sobraçando embrulhos, empurrando carroças carregadas, abrindo... caixas a transbordar de mercadorias... No pavimento das ruas... levantam-se a cada passo obstáculos. Ora é uma carroça atulhada de pipas... tomando metade da rua, ora é um formigueiro de negros conduzindo às costas sacas de café..." 22

E, em 1900, Joaquim Leitão narra, referindo-se às proximidades da Rua da Alfândega:

Lá de baixo, do bairro dos comissários, vem um cheiro sufocante a café em grão... Negros descalços, o tronco nu, reluzindo em camarinhas de suor, acarretam sacas de café para uma carroça; em cima, outro negro acomoda-as, empilhando-as ao longo umas sobre as outras, puxando pelas orelhas da linhagem. ${ }^{23}$

Essas são, portanto, informações cruciais para que se possa vislumbrar este acontecimento surpreendente - a Sociedade de Resistência dos Trabalhadores em Trapiche e Café cristaliza em uma instituição formal as estruturas informais dos grupos de trabalho surgidos nos arredores do porto desde o tempo do cativeiro, porém de modo ressignificado por alterações fundamentais. Os capitães, que antes do sindicato são eles próprios os empreiteiros da mão de obra, preservam sua posição diferenciada e continuam a fazer a mediação dos patrões com o mercado. O seu espaço de poder diminui, no entanto, significativamente. Como todos são membros de uma organização operária, a mediação deixa de ser entre os trabalhadores e os patrões, e passa a ser entre as firmas e o sindicato, isto é, entre os patrões e a coletividade organizada que, através de um corpo de fiscais, assume as tarefas de supervisão, disciplina, e escolha dos integrantes das turmas de trabalho, atribuições até então dos capitães e dos seus ajudantes. Aos fiscais cabe fazer cumprir o horário e as normas de trabalho decididas e aprovadas pelas assembleias gerais, órgão decisório máximo da associação.

O sentido e a força das palavras do velho operário adquirem, agora, uma clareza maior. Na ausência do sindicato, a mediação egoísta feita pelos capitães entre o mercado e o patronato provoca uma exploração desumana da força de trabalho e uma taxa irrisória de salário, com as quais lucram bastante, tanto os patrões como os capitães. Por isso as informações dadas sobre o chicote de barbante e a expropriação dos "quebrados", bem como os paralelos feitos entre o capitão e o senhor de escravos, e logo depois entre a fundação da Resistência e a Abolição. A "Resistência deu o grito do novo 13 de Maio" por significar o fim da sujeição "escrava” à autoridade arbitrária dos trabalhadores feitores ou capitães. É um "segundo nascimento" da condição liberta, um recomeço de histórias de vida. Mais ainda, a "Re- 
sistência deu o grito do novo 13 de Maio" por significar "liberdade" também em outro sentido, pois a junção dos capitães - os "ex-senhores" - com os seus subordinados em uma instituição única propicia o aparecimento de uma organização sindical atípica, que usurpa a principal esfera de ação patronal - o comando e o controle da produção - impondo-se aos comerciantes e trapicheiros como prestadora de serviços, através do conflito e da greve.

Diante deste fato inusitado, as reclamaçōes patronais recorrentes contra os fiscais aparecem igualmente sob nova luz, já que parecem querer dizer mais do que a mera intolerância para com o sindicato. Voltando, então, ao manifesto operário de 1906, é bom rever qual seria a natureza da liberdade almejada pelos trabalhadores. Será que compreendemos inteiramente a exortação: - "Avante! Vamos concluir o nosso direito, que... muito breve teremos a nossa completa liberdade"? Será que essa fala é outro sinal cifrado e indicativo de um elo ainda mais forte com o século XIX?

Já dissemos que a noção de "pertencimento" não esgota todos os sentidos que a ideia de liberdade tem para os cativos. Propriedades de outros indivíduos, quanto mais cerceados em suas ações, quanto mais espoliados em suas lidas, maior o espectro possível dos significados que os escravos conferem ao conceito. Com efeito, para eles, serem mais ou não serem nada livres são situações de vida e valores interligados, em formas e graus diversos, à possibilidade de disporem de si mesmos: dos seus corpos, dos seus passos, dos seus afetos, das suas crenças, das suas danças etc. e também dos seus próprios trabalhos. Ou seja, os significados da liberdade confundem-se com a luta pela alforria, mas também com diferentes formas e graus de autonomia arrancados ao controle senhorial. Autonomias concretas, vividas e ardorosamente defendidas, embora sempre ameaçadas pelos vínculos jurídicos que subordinam "propriedades" a "proprietários". Autonomias diversas, mas constantemente conjugadas à questão do trabalho, tema que nos interessa aqui mais de perto.

Há que se puxar, então, um fio da meada que vem tecendo esta exposição, para discutir melhor alguns aspectos do mercado de trabalho surgido nas ruas cariocas entre os muros escravistas. Não por desvalorizar as variáveis econômicas e, sim, em atenção ao argumento central desse artigo, começamos lembrando um fato notório, porém frequentemente desconsiderado nos estudos do mercado de trabalho - o de que sua análise não pode ser reduzida a consequências dos movimentos da economia, já que emprego, desemprego, profissões e nichos ocupacionais são também construçôes sociais. De alcance geral, esta proposição é, contudo, particularmente verdadeira para as grandes cidades do Império.

Nelas, na primeira metade do Oitocentos, quase todos os trabalhadores são escravos, ou seja, "propriedades” passíveis de furto, pois como assinalou o Ministro da Justiça Honório Hermeto Carneiro Leão, "esta propriedade não se guarda, anda pelas ruas, e aí está sujeita não só à violência, como as outras espécies de propriedade, mas também à sedução" ${ }^{24}$ Curiosa imagem esta - a sedução - que sintetiza em uma palavra, desqualificando, uma série de atos voluntários de propriedades que escapolem das mãos: fogem, formam quilombos, dizem-se livres, trocam de nomes, batucam, jogam capoeira, rebelam-se, matam. Propriedades que têm vida própria, e que, portanto, precisam ser vigiadas, submetidas e reprimidas, sempre. Chega-se, com isso, a algumas construçôes sociais dos dominantes. Nos contextos escravistas, incrustado aos mecanismos econômicos que explicam a existência desta ou daquela ocupação, há, via de regra, um conjunto importante de normas legais que, além de regularem o trabalho e desenharem lugares ocupacionais, visam antever e policiar possíveis ações rebeldes dos que labutam nas ruas longe do olhar senhorial.

É assim em todas as cidades brasileiras. No Rio de Janeiro, talvez mais ainda. Afinal, segundo declarações do mesmo Carneiro Leão, "em uma Capital como esta, em que há uma tão grande acumulação de ladrões e facínoras, e em que aportam tantos estrangeiros vadios, hábeis na arte de furtar”, é indispensável existir uma polícia muito bem montada. ${ }^{25}$ De fato, na Corte, desde os tempos da Guarda Real de Polícia (1809-1831), e desde que as atribuições das câmaras locais são definidas em lei (1828), au- 
toridades municipais e forças policiais militarizadas (apesar e a despeito dos seus aspectos patrimoniais) somam esforços para controlar a livre circulação não só dos escravos quanto dos pobres livres em geral - negros ou brancos, brasileiros ou estrangeiros.

O Código de Posturas de 1838 determina, por exemplo, que ninguém poderia ter escravos ao ganho sem tirar licença da Câmara Municipal, recebendo com a mesma uma chapa de metal numerada, a qual deveria andar sempre com o cativo em lugar visível, sob pena de oito dias de reclusão no calabouço. A regra é extensiva às pessoas livres, com a diferença de que estas deveriam apresentar um fiador a fim de conseguir a licença; de que os oito dias de prisão seriam na cadeia; e de que a esta penalidade se acrescentariam trinta mil réis de multa, se a chapa utilizada fosse falsa. Este mesmo código proíbe a quaisquer trabalhadores andarem gritando nas ruas, sob pena de dois dias de prisão e quatro mil réis de multa, e permite o canto africano para facilitar o trabalho; ordena a prisão dos cativos que fossem encontrados na rua depois das dezenove horas, sem explicação escrita pelo senhor, bem como dos marinheiros nacionais ou estrangeiros que andassem em terra à noite sob qualquer pretexto; estabelece também que as carruagens, carroças, seges, barcos, botes, canoas, ou saveiros seriam numerados a fim de serem licenciados e poderem andar de aluguel ou a frete. Já o regulamento da Praça do Mercado, de 20 de agosto de 1844, restringe o aluguel de suas bancas às pessoas livres; proíbe que os "pretos de ganho" andem dentro da praça, e que os escravos fazendo compras ali se demorem; reserva o lado direito da praia, em frente ao portão da praça, às embarcaçôes de pesca, e o lado esquerdo às canoas de ganho ou saveiros; interdita, no entanto, o acesso à praia às carroças de frete, determinando que os gêneros e objetos para embarque ou desembarque fossem "conduzidos apenas em cabeças de pretos". As posturas divulgadas pelo edital de 11 de junho de 1853 mandam, por sua vez, que além da licença municipal, todos os cocheiros matriculem-se na Repartição de Polícia a partir da data de sua publicação, sem o que não poderiam continuar a exercer o ofício. ${ }^{26}$

Esta medida estende as malhas do controle policial a um número enorme de imigrantes pobres. Entre 1850 e 1870, segundo as licenças concedidas pela Câmara, os lusos representam 73\% dos cocheiros com nacionalidade declarada. ${ }^{27}$ Esta relação percentual mantém-se relativamente constante nas décadas posteriores, e deve estar muito próxima à realidade do grupo. Em 1912, dos 2.333 sócios da Associação de Resistência dos Cocheiros, Carroceiros e Classes Anexas 73,2\% são estrangeiros, e destes quase todos imigrantes portugueses. ${ }^{28}$

Com isso não se quer dizer que o rigor é igual para escravos e livres, negros e brancos. Longe disso. Inúmeras posturas são concebidas para reprimir especificamente os negros, como a que torna ilegais as "casas de zungú", a que proíbe em recintos fechados os "batuques, cantorias e danças de pretos", ou a que ordena prender e aplicar cem açoites em qualquer cativo que estivesse fazendo desordens. Além do mais, muitas condutas criminalizáveis, a exemplo de "vozeria", "insulto", "desacato", "desordem" etc. dependem do discernimento do policial para serem vistas como transgressões, e os critérios de julgamento costumam variar de acordo com a cor da pele e a condição do suposto transgressor. Até a véspera da Abolição o arbítrio policial vitima os cativos com a sua violência desmedida, como atesta a aprovação pela Municipalidade de uma representação apresentada, em março de 1887, por José do Patrocínio, na qual ele pede ao Governo Imperial para agir "contra os maus tratos que a polícia desta capital inflige aos escravos [apreendidos], amarrando-os e espancando-os para obrigá-los a embarcar nas estradas de ferro e navios". ${ }^{29}$

Esses aspectos têm de ser considerados, é óbvio, mas de forma conjugada com outros, às vezes deixados na penumbra. Nesse sentido, é importante marcar que na Corte as normas do controle policial abarcam outros indivíduos, além dos escravos, dos libertos e dos homens livres "de cor". Como não poderia deixar de ser, os valores senhoriais e os a priori escravistas contaminam as relações sociais, atingindo também os operários livres e brancos. A exigência de fiador (de ser garantido por um homem de fé) como condição para que pessoas livres possam tirar licença para trabalhar ao ganho é apenas uma evidência, já mencionada, dessa contaminação. ${ }^{30}$ Parte-se, portanto, da suposição de que só um exame 
analítico abrangente das regras que modelam o mercado de trabalho pode iluminar as ações e reações dos que trabalham, trazendo-nos de volta aos ganhadores e aos últimos anos do escravismo.

Apesar das diferenças de tempo, ritmo e humores da luta contra a escravatura, expressas, por exemplo, nas palavras de Nabuco que, em 1884, saúda "a corrente abolicionista” como um "rio já formado" de "água cristalina" a "alagar" o país com uma "inundação enorme", ${ }^{31}$ e dois anos depois lamenta "a paralisação súbita da esperança", acusando o Imperador de "nunca" ter atravessado "a linha divisória entre a soberania do Estado e a soberania da Escravidão", ${ }^{32}$ uma questão emerge com nitidez na bibliografia acadêmica sobre o assunto. A partir da Lei do Ventre Livre, o ressentimento e o descontentamento galvanizam as hostes escravistas e cimentam sua ação em torno de três reivindicações básicas: crédito, braços e ordem. Crédito para irrigar a grande lavoura e indenizar a perda da propriedade escrava. Braços para continuar tocando os engenhos e cuidando dos cafezais, sem solução de continuidade. Ordem para controlar os libertos, reprimir a vadiagem, e impor a todos os pobres a disciplina apaziguadora do trabalho constante.

Consenso com relação aos fins, mas relativo dissenso com relação aos meios. Este é um tempo em que no Parlamento, nos Congressos Agrícolas e nas reuniōes dos clubes da Lavoura, proposições favoráveis à imigração europeia são atropeladas por demandas pela importação dos chins que, por sua vez, são contestadas por fortes preconceitos raciais; em que discursos liberais contrários à intervenção do Estado e animadores da ação privada das classes conservadoras apequenam-se e se destroem em contraditórios apelos por crédito barato; em que uns dizem confiar na utilização dos trabalhadores nacionais e outros afirmam que com eles não se pode contar. É que na hora de decidir o que fazer diante do crescimento assustador da vaga abolicionista, as opiniōes fragmentam-se sobre praticamente tudo, com uma exceção, talvez. Quase ninguém parece apostar na autorregulação do mercado de mão de obra. Em outras palavras, se a noção da "liberdade de contrato" orienta a ação dos patrões em 1918, o mesmo não acontece necessariamente nos anos 1880 e 1890 . Na verdade, no final do século XIX, no que diz respeito à força de trabalho, a maior parte das iniciativas pensadas para redesenhar os mercados de trabalho locais ou regionais não visa produzir a plena liberdade de mercado, mas sim o oposto. Conjuga-se fortemente com a tutela e o controle policial. ${ }^{33}$ É o que se procura mostrar a seguir.

É em dezembro de 1879 que José Antonio da Rocha Vianna, Chefe de Polícia da Bahia, escreve ao colega do Rio de Janeiro para pedir o envio com a brevidade possível "do regulamento ou outra qualquer disposição que sirva para a boa ordem e marcha regular do serviço de ganhadores nessa Corte", pois quer "também" regularizar na província este serviço, e deseja "harmonizar" as "disposições" que expediria "com a marcha aí seguida". ${ }^{34} \mathrm{O}$ que lhe foi enviado, não se encontrou, mas uma coisa é certa. Da iniciativa do Sr. Vianna surge o Regulamento Policial para o Serviço dos Trabalhadores do Bairro Commercial, assinado pelo seu sucessor, Virgilio Silvestre de Faria, em outubro de 1880. São fatos ocorridos na Bahia, mas que por contraste ajudarão a entender o que acontece no Rio. ${ }^{35}$

Golpe de mestre, segundo João Reis, em um longo processo de ensaio e erro das autoridades a fim de controlar as práticas coletivas de trabalho dos ganhadores africanos ou crioulos, escravos ou libertos das ruas de Salvador, as normas instituídas acabam por reconhecer formalmente a existência dos cantos e endossar sua estrutura interna de poder, ao tempo em que reduzem significativamente o seu espaço de autonomia. Entre outras determinações, o regulamento divide o espaço urbano em cantos A, B, e assim por diante "conforme a necessidade de sua colocação para a condução de objetos"; reparte os trabalhadores em turmas de tamanho ilimitado, aceitando que sua chefia continue a ser feita por um "capitão de canto" escolhido pelo grupo, porém com a necessária aprovação do Chefe de Polícia, que tem poder para destituí-lo sempre que julgar conveniente; dá liberdade de ação para o capitão organizar e comandar o processo de trabalho, mas o torna responsável perante o Chefe de Polícia pelas faltas cometidas pelos seus subordinados durante as horas de trabalho; ordena que o capitão comunique tais in- 
fraçōes ao Chefe de Polícia, e leve os infratores à sua presença para que possam ser legalmente punidos; exige ainda, que todos os ganhadores se matriculem na Polícia e se inscrevam oficialmente a um determinado canto, só podendo trabalhar os inscritos e matriculados, que adquirem, assim, o monopólio do trabalho. O regulamento traz, portanto, para a Bahia, um procedimento há muito utilizado na capital do Império - o registro policial de trabalhadores - conjugando-o a uma medida de feição abertamente antiliberal - a fixação geográfica da mão de obra e a criação de uma reserva de mercado para o trabalho daqueles que com suas normas procura controlar.

Como além desse estatuto também sobrevive à ação do tempo um livro de matrículas, datado de 1887, com informações detalhadas sobre os 1.703 operários filiados aos 89 cantos ali registrados, é possível saber a localização geográfica desses grupos de trabalho e o perfil sociológico dos seus membros. A maioria dos cantos, concentrando $82 \%$ dos trabalhadores, espalha-se ao longo do cais e se fixam junto aos armazéns, mercados, e casas comerciais da região portuária. Isso significa que os ganhadores atingidos pelo Regulamento de 1880 são em sua maioria carregadores envolvidos principalmente com o transporte de cargas e bagagem que transitam pelo porto.

Embora Reis tenha mostrado que há cantos em outras regiôes da cidade e que vários ganhadores não vivem apenas do trabalho de carregar, para os propósitos deste artigo é importante marcar apenas mais dois aspectos, dentre os muitos que sua análise ilumina. $\mathrm{O}$ primeiro diz respeito ao modo de trabalho dos ganhadores da área portuária. Segundo o autor, apesar de continuarem a carregar individualmente pequenos volumes, e em grupo cargas mais pesadas, na segunda metade do século XIX é possível que tenham passado a utilizar também carroças de duas rodas puxadas por burros, e pequenos carros com quatro rodas que eles próprios puxavam. ${ }^{36} \mathrm{O}$ segundo refere-se à composição social da força de trabalho. Exceto alguns escravos, pouquíssimos, e quatro homens classificados como brancos, os ganhadores são quase todos negros livres e libertos, o percentual dos africanos sendo um pouco menor do que o dos crioulos. Mais da metade é gente de fora da cidade, mas da província da Bahia. Entre os brancos, não há sequer um único imigrante. ${ }^{37}$

$\mathrm{Na}$ Corte, apesar da invasão dos imigrantes e da frequência dos discursos alusivos às nações livres, cultas e civilizadas, é possível notar-se a mesma reserva com relação ao livre funcionamento do mercado de mão de obra, e a mesma apreensão com a morte anunciada da escravatura. A questão aparece claramente nas discussões sobre a locação dos serviços domésticos. No relatório referente a 1880, o Ministro da Justiça alerta:

É geralmente sentida a necessidade de uma lei para regular os direitos, deveres e penas dos que se empregam, assalariados, nos serviços domésticos. Com o decrescimento da população escrava, aplicada de preferência a esses labores, a falta se vai tornando cada vez mais clamorosa.

Sem matrícula que facilite a inspeção da autoridade... existe um grande número de nacionais e estrangeiros que vivem numa espécie de vagabundagem intermitente. Iludem... a boa fé dos amos, alegando falsas aptidões e qualidades, pretextam contrariedades para despedir-se, algumas vezes levados por seduçôes, por ganância ou pelo desejo de desfrutar no ócio o salário acumulado. ${ }^{38}$

O problema é delicado, e o terreno escorregadio. Mesmo assombrados pelos fantasmas que do futuro parecem estar a espreitá-los, não é fácil, para senhores acostumados com a irresponsabilidade do domínio senhorial, admitir a interferência do poder público sobre o que acontece entre as quatro paredes do lar. Por outro lado, a lei não poderia ser uma prisão a garantir por certo tempo o cumprimento obrigatório dos contratos de locação. Afinal, segundo o Ministro, e é preciso explicitar aqui o não dito, "[na nova situação de liberdade] ninguém quereria expor-se aos perigos de ter ao seu serviço pessoas constrangidas". ${ }^{39}$ A solução proposta é um controle individualizado e imobilizador, mas externo à casa do patrão - a matrícula geral que a polícia organizaria, por distritos de paz, de todas as pessoas livres que desejassem se empregar em serviços domésticos. 
Neste intento ele não está sozinho. Nas décadas de 1880 e 1890, as autoridades municipais, imperiais e republicana concebem vários projetos visando registrar e normatizar o trabalho doméstico - mas sempre em vão. ${ }^{40}$ Além do dissenso das elites quanto ao valor da medida, também há a resistência dos subalternos. Em 1905, os executores da Consolidação das Leis e Posturas Municipais do Distrito Federal ainda reproduzem um regulamento para tais atividades, com o lamento de que empregados vadios, "contando com a proteção dispensada por proletários que se encarregam de outros misteres", possam impor ao patrão "condiçôes que não se exigem em qualquer outro meio". E explicam:

Provindo uns das antigas senzalas, descendentes outros de escravos libertos, grande número de criados, sobretudo do sexo feminino, consideram como meio coercitivo de sua liberdade a obrigação de certos e determinados serviços, impondo as horas e a espécie do seu trabalho quotidiano e não tolerando qualquer admoestação ou advertência, por mais branda que seja. ${ }^{41}$

Diante de tal afirmação, reveladora de expectativas muito pouco condizentes com a "liberdade" própria das relaçôes contratuais "modernas", e diante do clamor existente no final do século XIX contra a vadiagem e a desordem que supostamente perturbam a vida dos cidadãos honestos no centro nervoso do país, difícil não intuir que cedo ou tarde chegaria a vez do trabalho de rua. E de fato chega. A 2 de março de 1886, um edital municipal divulga o Regulamento dos Ganhadores aprovado no ano anterior e que estende o controle policial a esses trabalhadores, logo seguido pela abertura do respectivo Livro de Matrículas na Repartição de Polícia, de 20 de junho em diante. Apesar deste livro não ter sido encontrado, cruzando-se fontes diversas é possível afirmar que no Rio de Janeiro os caminhos dos ganhadores se separam, e nada acontece de modo exatamente igual à Bahia.

A primeira diferença é conhecida. Refere-se à forte presença imigrante entre a população pobre que labuta nas ruas da cidade, e será abordada a partir dos pedidos de licença encaminhados à municipalidade pelos "Ganhadores Livres" e seus fiadores. São três séries de registros, duas de uma irregularidade extrema. A primeira vai de 1858 a 1870 e contém 54 solicitações. A segunda reúne 523 petições, todas encaminhadas entre 25 e 31 de julho de 1879 , ou seja, em um curto intervalo de seis dias. A última agrupa 58 requisições registradas entre março de 1880 e julho de 1886, época em que o Livro de Matrículas já estava aberto na Polícia. Há ainda um conjunto de documentos classificados à parte, sob a rubrica "Africanos Livres ao Ganho". Vai de 1855 a 1880, e contém oito pedidos de licença. ${ }^{42}$

Excluindo os 302 casos para os quais não se tem qualquer informação sobre a cor ou a nacionalidade dos indivíduos, obtém-se o seguinte retrato do grupo: 193 trabalhadores (56,6\%) são brancos, 126 (37\%) são negros libertos, e 22 (6,4\%) são brasileiros, sem indicações de cor. Entre os negros existem crioulos, é claro, e vários cuja nacionalidade e/ou etnia não pode ser identificada, mas 91 (72,2\%) são africanos, e destes 48 (52,7\%) são minas. Os brancos, por sua vez, são todos imigrantes, e reúnem 131 (68\%) portugueses, 37 (19\%) italianos e 25 (13\%) espanhóis.

Esses dados surpreendem. Não tanto pela maioria de imigrantes que revela entre os ganhadores livres, embora misturada a um montante nada desprezível de negros libertos, mas principalmente pelo número insignificante dos pedidos encontrados em comparação com o universo provável de pessoas que dependem de pequenos expedientes para sobreviver. Segundo o Recenseamento de 1872, habitam no Município Neutro 147.119 pessoas livres e escravas classificadas em "serviço doméstico" e "sem profissão", categorias censitárias à parte da dos "jornaleiros e criados assalariados". Como as donas de casa, crianças e adolescentes estão aí misturados, excluindo todas as pessoas do sexo feminino computadas em ambas as categorias, bem como o contingente de menores de 16 anos do sexo masculino estimado na população geral, chega-se a um total aproximado da ordem de 19.000 adultos do sexo masculino. ${ }^{43}$ Uma porcentagem considerável desses homens, a maior parte gente livre, está com certeza na batalha das ruas, sendo certo que esse conjunto de pessoas livres só faz crescer daí por diante. Com tamanha disparidade entre a quantidade de petições e a de indivíduos sem uma profissão claramente definida, os números falam por si e nos dizem que os pedidos de licença analisados não constituem uma amostra se- 
gura para o estudo da composição social da força de trabalho. Seu valor parece ser outro. Mais do que distribuições estatísticas, essa documentação provoca interpretações qualitativas. Por intermédio de suas lacunas fala de resistências subterrâneas - o que não deve admirar.

Esparsas em diferentes fontes há indicaçôes de que os imigrantes saem ao ganho sem querer tirar licença. $\mathrm{O}$ mesmo pode acontecer com os libertos e brasileiros pobres, já que a exigência de fiador pressupõe relações de proteção e dependência que muitos homens livres não têm, ou podem escolher não ter. Esta é uma chave de leitura possível para a escassez e a irregularidade das solicitações computadas ser o testemunho de contestações e não só da ação corrosiva dos anos. A existência entre 1851 e 1870 de 1.627 requisições de licença de senhores de escravos, contra apenas 54 de "Ganhadores Livres" entre 1858 e 1870, torna verossímil essa hipótese, não só porque este é um período de crescimento da mão de obra livre, mas porque é estranho que o tempo penalize só uma parte escolhida da documentação. Por outro lado, a própria enxurrada de 523 petições registradas em seis dias cheira à repressão e sugere que os fiscais municipais estavam em campo distribuindo multas nas ruas. As indicações mais diretas de que as posturas podem ter sido desrespeitadas estão, entretanto, na última série cronológica de pedidos, e nos relatórios policiais e dos Ministros da Justiça.

A partir de 1886, todas as petições requerendo licença para ganhador (exceto uma, apresentada por Francisco Congo) anexam matrículas efetuadas na Polícia (que, aliás, substituem os fiadores), mas os pedidos logo se interrompem. Pelos relatórios ministeriais comprova-se, todavia, que a matrícula foi posta em prática - com uma irregularidade flagrante. Em 1905, Cardoso de Castro, Chefe de Polícia do Distrito Federal, comenta que a matrícula policial anual foi criada em 1886 por uma lei que não diz a quem compete fiscalizar o serviço. E para provar "o prejuízo que a Prefeitura tem em licença de ganhadores", apresenta a seguinte estatística: ${ }^{44}$

\begin{tabular}{|c|c|c|c|}
\hline Anos & No de matrículas & Anos & No de matrículas \\
\hline 1891 & 900 & 1898 & 321 \\
\hline 1892 & 1049 & 1899 & 464 \\
\hline 1893 & 300 & 1900 & 383 \\
\hline 1894 & 300 & 1901 & 144 \\
\hline 1895 & 600 & 1902 & 153 \\
\hline 1896 & 600 & 1903 & 217 \\
\hline 1897 & 300 & 1904 & 477 \\
\hline
\end{tabular}

Para ele, esses dados não se devem a resistências, mas sim ao descaso da burocracia, pois em sua opinião os registros só aumentam quando há reclamações. É claro que uma razão não exclui a outra, e que a irregularidade pode estar relacionada a ambos os fatores. Há que se indagar então: quem são realmente esses ganhadores livres que parecem tanto acatar quanto fugir da matrícula? Será que a proporção (56,6\%) de imigrantes identificada na documentação municipal pode ser ainda maior? Nesse caso, o que acontece com os escravos de ganho regularmente licenciados pelos seus senhores que, na contagem de Soares, somam 2.823 homens entre 1851 e $1870 ?{ }^{45}$ Onde estão os "trabalhadores de tropa" que nos primeiros anos da República são quase todos "homens de cor"? Não são eles também "ganhadores"?

Como não se tem os livros de matrícula, onde deviam ser anotados o nome, o endereço, a idade, a naturalidade, o estado, a cor e os sinais particulares de todos os matriculados, a resposta implica um caminho mais tortuoso e que leva a um segundo contraste com a Bahia.

Diferentemente da capital baiana em que o Regulamento Policial para o Serviço dos Trabalhadores do Bairro Commercial endossa e normatiza práticas de trabalho coletivo, na Corte o Regulamento dos Ganhadores cria regras para atividades individuais. Alguns dos seus artigos determinam que o ganhador só pode "estacionar" "no ponto" designado em sua matrícula; que aí ele é obrigado a "sujeitar sua matrícula ao visto do delegado de polícia"; que é proibido aos ganhadores "aglomerarem-se, atropelando os 
transeuntes"; que não é permitido aos ganhadores disputarem "entre si" a preferência de um carreto; que o dono da carga tem o direito de escolher "aquele" que desejar. ${ }^{46}$

A natureza e o modo de trabalho desses indivíduos, bem como a composição social do grupo ficam, todavia, mais claros, nas evidências surgidas com o seu processo de organização. Para as assembleias da Sociedade Cosmopolita de Beneficência dos Ganhadores, fundada em 1902, são convidados apenas "os carregadores de carrinho de mão". ${ }^{47}$ Já suas ações confirmam que eles são uma fração de classe submetida ao controle do poder público. Em janeiro de 1903, os ganhadores reúnem-se para tratar dos seus interesses "ameaçados pelo prefeito municipal", e em novembro de 1906, para mandar uma representação ao chefe de polícia, pedindo o "restabelecimento dos pontos de estacionamento dos carrinhos de mão". ${ }^{48}$ Em 1916, em lugar da Beneficência dos Ganhadores existe o Centro Social Beneficente dos Carregadores do Distrito Federal, fundado "para melhor defesa contra injustas perseguições”, e fornecimento de advogado para defesa dos sócios "ante a Polícia, Prefeitura e órgãos judiciários, quando... vítimas de má interpretação relativamente aos regulamentos em vigor”. Do Centro participam 1.310 associados, dos quais $1.044(79,7 \%)$ são estrangeiros. ${ }^{49}$ Este é, portanto, um conjunto de operários distinto daquele constituído pelos "trabalhadores de tropa", que trabalham em grupo e são de maioria negra.

Em síntese, no Rio de Janeiro do final do século XIX, o termo "ganhador" não tem mais a abrangência de cinquenta anos atrás. Categoria usada inicialmente para nomear negros escravos ou libertos envolvidos em um conjunto diferenciado de ocupações que os faziam trabalhar de modo individual ou coletivo, a palavra passa posteriormente a designar também pessoas livres e brancas, porém com um sentido ocupacional cada vez mais restrito. Atividades como pescar, vender, barbear, engraxar, amolar desprendem-se do seu campo semântico e passam a ser vistas como ocupações que têm designaçõos específicas. Assim, em 1886, ano em que o Regulamento dos Ganhadores é implantado na Corte, o termo "ganhador" parece já qualificar de modo prioritário a ocupação de indivíduos que transportam cargas, principalmente bagagem e pequenos volumes, cada um por si, em seus próprios carrinhos de mão. São esses homens, em grande parte imigrantes, que acabam enredados nos nós do controle policial. Segundo o Guia do Viajante do Rio de Janeiro, podem ser encontrados em grande número "no cais Pharoux e em quase todas as esquinas na parte de maior circulação da cidade", trazem consigo no peito ou no bolso "uma chapa numerada que são obrigados a apresentar em caso de exigência", e "em geral são carregadores fiéis" . ${ }^{50}$

$\mathrm{Na}$ comparação do Rio com a Bahia duas questões merecem ser sublinhadas. A primeira tem a ver com a ambivalência das atitudes patronais com relação ao que se diz ser na época a tragédia "da emancipação imediata do elemento servil, sem organização do trabalho livre", isto é, sem "medidas salutares para o seu desenvolvimento". ${ }^{51}$ Misturada à crença de que sem o controle senhorial o liberto cairia na vadiagem, o que se deduz de afirmaçôes como essa é a pouca valorização da flexibilidade característica da "sociedade de mercado", flexibilidade que os patrōes parecem não saber ainda como utilizar em proveito próprio. A ideia de um mercado autorregulado, da mobilidade geográfica do trabalhador, da liberdade total de contrato não está em seus horizontes. O que se deseja é uma oferta segura e constante de mão de obra; é o trabalho tutelado, aprisionado por regras imobilizadoras, fixado a um lugar.

$\mathrm{Na}$ Bahia há outras iniciativas neste sentido, como o Regulamento Policial para o Serviço de Ganhadores de Cachoeira, aprovado em 1890, ou o Código Rural de 1893, que, tudo indica, só não é sancionado pela Assembleia Legislativa em função da mobilização feita pelo Centro Operário. O Regulamento de Cachoeira cria quatro turmas fixas de cinquenta ganhadores, distribuídas dentro da cidade pelo delegado de polícia, e das quais nenhum trabalhador pode sair para ir trabalhar em outra, sem averbar a mudança no livro da municipalidade. ${ }^{52} \mathrm{O}$ Código divide toda a área do estado fora dos limites urbanos em um número equivalente de distritos rurais e policiais, mas não se limita a regular o trabalho rural. Além das regras instituídas para vigorar no campo, prevê multa ou prisão por quinze dias de qualquer 
pessoa maior de dezoito anos que não possa provar ocupação nas cidades e vilas, determinando que as reincidentes sejam remetidas para estabelecimentos agrícolas com garantia de juros ou para colônias correcionais, onde deveriam assinar contratos de trabalho de pelo menos um ano de duração. ${ }^{53}$

A segunda questão está relacionada ao fato dos ganhadores serem operários que não constituem, nas duas cidades, grupos inteiramente equivalentes. Diversamente de Salvador, no Rio o termo "ganhador" adquire um significado mais restrito, que não abarca os grupos de trabalho liderados pelos capitães, então conhecidos como "trabalhadores de tropa", formados majoritariamente por "homens de cor", mas que no final do século XIX também incluem alguns operários imigrantes. Ora, as transformaçōes semânticas nunca são inocentes. Estes indivíduos, que em turmas fixas por relações costumeiras fazem o manejo de café nos armazéns dos comissários, transportam à cabeça sacas de café, ou carregam e descarregam carroças, constituem uma fração de classe que desaparece dos pedidos de licença municipais e escapole da matrícula policial. Esse fato tem um significado fundamental. Numa época repressiva, em que dispositivos de fiscalização e enquadramento são repetidamente pensados para tutelar e submeter os operários, sobretudo aqueles que trazem no corpo a marca da escravidão, os "trabalhadores de tropa" conseguem manter-se à margem dos controles policiais, preservando um espaço de autonomia que vem do tempo do cativeiro. É nesse mundo periférico que instituem um "campo negro", apropriando-se de territórios e tecendo redes de relações com este comissário ou aquele trapicheiro. É nesse espaço que constroem, portanto, o que chamam de nosso direito e de nossa liberdade - em poucas palavras, o seu trabalho.

Só em 1889 é que as autoridades, apercebendo-se, talvez, dessa resistência subterrânea, introduzem um adendo ao final do Regulamento do Serviço Doméstico, para resolver o problema. Neste, definem como "carregador" aquele "que exerce a indústria de transporte manual de cargas"; instituem toda a parafernália usual de monitoração (licença, matrícula policial, chapa, controle de endereço, multas, prisão); e tentam liquidar a questão, esclarecendo que as disposições são aplicáveis também "aos indivíduos empregados como auxiliares nos veículos de transporte de cargas". ${ }^{54} \mathrm{Ou}$ seja, os novos preceitos buscam abarcar tanto os grupos de trabalho que transportam sacas à cabeça - o formigueiro de negros percebido por João Chagas - como aqueles que carregam e descarregam carroças - os negros vistos trabalhando no bairro dos comissários por Joaquim Leitão.

O interessante é que no Código de Posturas organizado em 1905 para consolidar a legislação municipal e federal ainda passível de aplicação na cidade, essas normas não aparecem mais, e nada é dito sobre o assunto, o que indica que as regras são palavras escritas e jogadas ao vento. Os "trabalhadores de tropa" simplesmente as ignoram. Permanecem na sombra com suas relações sociais costumeiras, sua autonomia grupal e o seu trabalho, aproveitando a confiança dos comissários, que continuam a usar os seus serviços sem exigir a apresentação da matrícula. É este o costume aludido por Muñoz na mesa de negociaçôes, "costume" que por não ser mais "aceito sem recriminaçôes" parece estar no âmago das disputas de 1918.

Voltamos, assim, ao manifesto operário de 1906, e com ele a um elo profundo de ligação com os estudos mais recentes sobre a escravidão. Na raiz da fundação da Sociedade de Resistência, associação criada desde o início com a finalidade de "contratar os trabalhos que lhe pertencem", 55 há valores e noções de direito muito semelhantes àqueles que fazem libertos lutarem no pós-abolição por roças cultivadas nas fazendas com a permissão dos senhores. Concepções de direito que conjugam a ideia de liberdade com a autonomia gerada pela "propriedade" do próprio trabalho, e que no limite podem perigosamente chegar até a noção da propriedade dos meios de produção.

Segundo José de Souza Martins “a extinção da escravidão não produziu o proletário da fábrica”, mas antes, "a categoria ambígua do trabalhador livre". Ambígua porque marcada pelas relações entre senhores e escravos, e definida pelo pressuposto ideológico de que livre era "um trabalhador que trabalhava para si mesmo, ainda que disfarçadamente estivesse preso a uma complicada teia de dependências sociais, de mando, de pobreza e de opressão". ${ }^{56}$ A "gênese da condição operária" estaria, então, "na expropriação" deste "trabalhador pré-capitalista ou não-capitalista, que o lança numa relação de exploração, 
cujo sentido se define pela mediação do confronto e do conflito das classes" ${ }^{57}$ Ao fazer essas considerações, Martins não está pensando no ex-escravo, que ele concebe nos termos da análise sociológica de Fernandes, e sim no colono europeu de poucos recursos, vindo para o Brasil em busca de uma vida melhor. De modo contraditório, porém, a sua análise serve perfeitamente para o liberto, sobretudo se for considerado que essa expropriação pode ser também apenas de sonhos e aspirações.

Sobre a conversão do liberto em operário sindicalizado é importante fazer, contudo, uma observação. Embora seja correto sustentar que "de variadas maneiras, as vivências da escravidão se projet[am] sobre o período pós-abolição, definindo e orientando escolhas, atitudes, expectativas e sentidos da liberdade" ${ }^{58}$ é igualmente correto afirmar que o entrelaçamento desse mundo subjetivo e dessas vivências nos movimentos operário e sindical não é uma simples projeção.

Em artigos anteriores mostramos que a Sociedade de Resistência é uma organização operária surgida em um campo complexo de relações sociais, no qual se chocam interesses, tensões, solidariedades e conflitos diversos, sendo, por conseguinte, fruto de um processo histórico de apreensão difícil, pelas diferentes conexões de interdependência dos elementos que o compõem. Indicamos, então, que os trabalhadores sindicalizam-se sob a liderança do negro fluminense Cândido Manoel Rodrigues, "capitão de tropa" de uma das unidades mais importantes do sistema portuário carioca. Impulso organizador que relacionamos a uma série de fatores (autonomia específica dos capitães; sua posição ambígua como elementos de confiança e ligação entre os patrões e as "tropas"; solidariedades grupais prováveis; conflitos plausíveis entre "tropas" competidoras; e estratégias patronais possíveis de substituição dos brasileiros em posições de mando no mercado de trabalho), mas que não consideramos como a explicação única do fenômeno.

Embora pouco se saiba sobre a dinâmica interna e a estrutura de poder dos grupos de trabalho preexistentes à Sociedade de Resistência, as evidências disponíveis são claras em mostrar que os capitães estão longe de serem, eles todos, líderes altruístas. Alguns chegam até a roubar os membros da "tropa" sem admitir protestos, como se vê no caso contado por um trabalhador do trapiche Matos. Em carta endereçada ao Jornal do Brasil, dois anos antes da fundação da Resistência, ele relata que numa quinta-feira, após o serviço, foi ao hotel onde estava o capitão e lhe exigiu o pagamento do seu trabalho. Todavia, em vez de ser pago, foi levado à presença de um policial, que o espancou e prendeu devido às mentiras inventadas pelo capitão. ${ }^{59}$

Se capitães podem ser comparados a senhores de escravos, e a Resistência a um novo 13 de Maio, é porque o "direito" e a "liberdade" mencionados no manifesto de 1906 não são presentes graciosos de chefes a comandados, nem muito menos a continuidade de uma tradição preservada. Como afirma o militante José Arias de Castro, escrevendo em 1916 sobre a greve de dez anos atrás, "a liberdade e o bom trato não nos são doados por quem quer que seja: é (sic) sempre uma conquista imposta pelos oprimidos e mal tratados" ${ }^{60}$ Deste modo, mesmo num movimento sindical liderado por um capitão, é necessário enxergar nos fatos a revolta de centenas de homens explorados e espezinhados que, se organizando, conquistam respeito e dignidade, além de condições de trabalho mais justas e transparentes. Para tanto, subvertem hierarquias de poder internas às "tropas" a partir de uma lógica igualitária estranha à cultura africana e até então inexistente. Deixam de ser grupos de trabalho fortemente hierarquizados e passam a constituir "uma família" de iguais, o que só é inteligível se levarmos em conta a politização das mensagens de esquerda e da dinâmica coletiva dos movimentos operários classistas.

Esses e outros aspectos inscritos no processo de sindicalização dos trabalhadores de tropa já foram discutidos, e não há porquê resumir tudo o que dissemos sobre o contexto e o tema. $\mathrm{Na}$ organização da Resistência existe, entretanto, uma dimensão ainda não explorada inteiramente. Chama a atenção a ênfase dos operários que, no manifesto de 1906, falam não só em "nosso direito" e "nossa liberdade", como também em "nossa completa liberdade". O que daria à liberdade tal qualidade de completa? Esta pergunta está ligada às reclamações patronais contra os fiscais, último aspecto que importa examinar. 
Como o fragmento citado no início do artigo deixa entrever, o manifesto é redigido num momento em que a Resistência está em greve. Parte do significado da adjetivação em tela tem a ver com um dos objetivos deste conflito de dezembro - "concluir o nosso direito", isto é, completar um processo de conquistas, obrigando os trapiches que ficam fora dos acordos alcançados em agosto a assinar finalmente "o contrato" com a associação. Se relacionarmos, contudo, a noção de "completa liberdade" a uma ideia expressa num outro panfleto também distribuído neste movimento, perceberemos que a resposta é apenas a ponta mais visível do iceberg. Dirigido aos companheiros e às autoridades da $3^{\text {a }}$ urbana, neste segundo manifesto, os operários comparam-se aos policiais militares e afirmam que, tal como eles, os soldados sofrem "mil infâmias" e "misérias", mas são "mais martirizados", porque "em vós todos mandam, e vós não mandais em ninguém" ${ }^{61}$ Esta ideia de um martírio maior dos soldados rasos, fruto da sua inteira subordinação, tem uma dimensão política que dá o que pensar.

$\mathrm{Na}$ discussão feita sobre o mercado de trabalho soteropolitano e carioca, procuramos indicar que, após a Abolição, o imperativo (imposto pela ideologia do mercado) de se redefinir o conjunto das relações de trabalho em convenções contratuais "modernas" representa, para os dominantes, uma ruptura traumática não necessariamente aceita de imediato. Os regulamentos de trabalho mencionados mais atrás ganham sentido nessa conjuntura, em que tudo lhes parece ameaçador e toldado pelo temor de que os libertos constituíssem uma espécie de povo independente e degenerado, algo como uma nação libertina e indolente, sem lei, sem religião, e sem polícia, à qual viriam se integrar os imigrantes vagabundos e indesejáveis. Daí o veio repressivo dos governantes e a busca obsessiva pela tutela dos subalternos, com a multiplicação das regras que buscam erradicar a mobilidade da mão de obra, enquadrando-a em estatutos rígidos de organização e fiscalização do trabalho.

Mas não são apenas os regulamentos que adquirem sentido nesta conjuntura. $\mathrm{O}$ mesmo pode-se dizer da Sociedade de Resistência, pois imiscuídas em seu surgimento estão tanto as regras que visam controlar os operários quanto as atitudes que elas provocam em uns e outros - dominadores e dominados. Nessa perspectiva, é importante notar que naquele período, o cotidiano dos trabalhadores de rua configura-se como um campo de forças, no qual os confrontos em torno de regras acontecem em todas as esquinas. Aqui são meninos, apanhados vendendo bilhetes com licença passada em nome de outrem. Ali é um ganhador que estaciona num local indevido, e é destratado por um policial. Lá é um carroceiro, multado por seu carregamento estar acima do peso permitido, que perde a cabeça e acaba na prisão.

No início da República, esses embates originados das "medidas salutares para o desenvolvimento do trabalho livre" explodem todo dia, adentram as noites, e invadem casas, tavernas e botequins. É que a tutela dos governantes, com suas proibiçóes e interditos, procura regrar o lazer do operário, quase tanto quanto o seu trabalho. Nada de muita festa, jogos, sambas, de "ajuntamentos" suspeitos, enfim. O espírito repressivo das posturas imperiais é preservado com cuidado, porque se considera fundamental combater a vadiagem e ensinar aos pobres a "virtude do trabalho", isto é, o ato de trabalhar sem objetivo, de trabalhar por trabalhar. ${ }^{62}$ Ninguém fica, portanto, alheio às regras disciplinares e aos conflitos daquela hora.

Contudo, de quais regras estamos falando? Recém-chegado à Corte, Kozeritz escreve, em 1883, que "o Rio de Janeiro é o Brasil, e a Rua do Ouvidor é o Rio de Janeiro". ${ }^{33}$ Ele refere-se aos "homens que governam o país e conduzem a opinião pública”, mas se mirasse o povo decerto notaria que por suas características específicas os bairros portuários são a Rua do Ouvidor dos governados. Numa sucessão de mais de sessenta trapiches, o sistema portuário espalha-se por toda a orla de Santa Rita e Santana, confundindo-se com a cidade, pois não há muralhas que o seccionem da malha urbana. Essa interconexão é particularmente relevante porque na área existem vários estaleiros, oficinas metalúrgicas, serrarias, carpintarias, tanoarias, grandes empreendimentos fabris de importação e moagem de trigo, fabriquetas de vários tipos, e até uma fábrica de fiação e tecelagem, além de muitos estabelecimentos comerciais, armazéns, botequins, tavernas e cortiços. Ademais, é importante lembrar que desembarcam anualmente 
no porto milhares de pessoas oriundas do estrangeiro ou dos quatro cantos do país. Em 1903, ano da primeira greve geral carioca (que, aliás, paralisa o porto), aí chegam 18.170 indivíduos vindos somente dos outros estados da República. ${ }^{64}$ Com tamanho trânsito humano e tão forte presença operária, a região é um espaço claramente estratégico para a troca das experiências subalternas. Não deve surpreender, portanto, que operários industriais, marinheiros, estivadores, carroceiros e "trabalhadores de tropa" cruzem nas suas conversas o cotidiano da fábrica com o do mar e do porto; que vivências de exploração sejam analisadas e contrastadas por libertários, socialistas, republicanos e apolíticos; que regras e regulamentos locais e forâneos sejam discutidos e conhecidos; e que nas asas da esperança socialista, a imaginação possa voar até bater em outras terras.

Orientado pela concepçáo de que o poder possui uma forma capilar de existir, e de que a entrada em cena de novas forças designa um lugar de confronto indeterminado, pois advém de uma luta disseminada por toda a estrutura social, Foucault afirma que, em cada momento da História, a dominação se fixa num universo de regras. "A regra é o prazer calculado da obstinação... permite reativar sem cessar o jogo da dominação". A seu ver, todavia,

é justamente a regra que permite que seja feita violência à violência e que outra dominação possa dobrar aqueles que dominam. Em si mesmas as regras são vazias, violentas, não finalizadas; elas são feitas para servir a isto ou àquilo... O grande jogo da história será de quem se apoderar das regras, de quem tomar o lugar daqueles que as utilizam... para pervertê-las, utilizá-las ao inverso e voltá-las contra aqueles que as tinham imposto; de quem, se introduzindo no aparelho complexo, o fizer funcionar de tal modo que os dominadores encontrar-se-ão dominados por suas próprias regras. ${ }^{65}$

Essa proposição é instigante, porque, ao se organizarem, os "trabalhadores de tropa" parecem inverter e se apropriar de normas criadas para fixar a força de trabalho e controlar os cantos soteropolitanos. É como se o regulamento policial baiano aparecesse travestido em sindicato no Rio. Lá, o Chefe de Polícia estabelece o monopólio do trabalho de grupos matriculados na chefatura e controla o capitão a fim de submeter e disciplinar os operários. Aqui, capitães e trabalhadores unidos estabelecem o monopólio do trabalho de grupos matriculados na Resistência, a fim de controlarem e disciplinarem a si mesmos. Lá, a autoridade e as decisões do Chefe de Polícia, as penalidades do Estado, a ação dos seus representantes - e regras que subordinam. Aqui, a autoridade da classe, as decisões e penalidades da Assembleia Geral e do Conselho Diretor, a ação dos fiscais sindicais - e regras que libertam. ${ }^{66}$

São as dimensões econômicas e políticas da tomada do mercado e das regras disciplinares que melhor explicam a noção de uma liberdade completa dos "trabalhadores de tropa" sindicalizados. ${ }^{67}$ Completa não só porque se tem agora um trabalho fixo e resguardado para todos, mas também porque agora as regras controlam e disciplinam até o patrão. O fato, corroborado por inúmeras fontes, é didaticamente explicado pelo velho trabalhador ao repórter, a fim de fazê-lo compreender por que afirma: "Nós que rastejávamos, levantamo-nos; nós que éramos escravos, tornamo-nos cidadãos". Para tanto, dá exemplos de situações concretas. Num deles expõe:

- Um carregador qualquer.. para fazer o carreto de um saco de café cobra no mínimo $3 \$ 000$. A tropa está fazendo uma carga... Chega um patrão... e manda um trabalhador fazer o carreto. Aquele trabalhador desviado do serviço durante duas horas... teria carregado 50 sacos. Não os carregando... prejudicará os companheiros em $4 \$ 000$. O patrão não paga o carreto ao trabalhador que foi cumprir sua ordem, não paga à tropa a diferença. Se o que carregou o saco protesta, é DESPEDIDO. O fiscal intervém e dá direito a quem tem, isto é, o trabalhador. O patrão esbraveja: está na sua casa, ele é que manda. Mas há um engano. $\mathrm{O}$ trabalhador não tem ordenado, não é empregado. Se não há saco para carregar, ele morre de fome, não ganha vintém. É justo que... trabalhe de graça para o comerciante de café? Não. Mas o fiscal leva uma carga de ódio do patrão. ${ }^{68}$

Ou seja, com a Sociedade de Resistência, uma subordinação "escrava", produtora de um martírio comparável ao do soldado raso, desaparece, e em seu lugar surge uma liberdade feita de direitos e autonomias, uma liberdade completa, "cidadã". Parafraseando Foucault, é possível dizer que a Resistência "é 
uma relação de forças que se inverte, um poder confiscado, um vocabulário retomado e voltado contra seus utilizadores, uma dominação que se enfraquece... e uma outra que faz sua entrada". ${ }^{69}$ É esse "acontecimento", esse radicalismo do desenho institucional e das açōes da Sociedade de Resistência, que tira o sono dos patróes e provoca a sua raiva indignada - verem-se presos em regras pensadas para enquadrar e controlar operários filhos do cativeiro.

Quem sabe se não é esse contragolpe de mestre dos "trabalhadores de tropa" que ensina aos comissários de café e comerciantes cariocas que na sociedade capitalista as "forças do mercado" e a "liberdade de contrato" são para eles um trunfo muito melhor do que a tutela?

A pesquisa subjacente a este trabalho é orientada por pressupostos que agora podem ser explicitados.

O primeiro refere-se ao tema da chamada "transição". Parte-se da certeza de que a criação de um mercado de trabalho "livre" não se produz de forma mecânica e homogênea, como se existisse em todos os lugares um espelho a refletir sempre a mesma imagem. Apesar do prestígio da economia política e da vitória do liberalismo econômico, a "sociedade de mercado" é, na verdade, uma miragem defendida e atacada durante séculos, e que nunca existiu nem existe empiricamente sem "distorções". Com resultados sempre desiguais, é fruto de conflitos específicos e historicamente determinados, entre os quais têm proeminência as lutas de classe e, com elas, os movimentos operário e sindical.

O segundo é a presunção de que esses movimentos coletivos são o resultado de duas linguagens entrelaçadas. Uma é a do cotidiano da ação política. Remete-nos aos atores, às organizações, aos projetos políticos, e às ideologias formalizadas. É uma linguagem de resultados, de vitórias ou fracassos, e que só pode ser analiticamente reconstruída no plano macrossociológico das relações de força inseridas no contexto global em que ocorrem. A outra é a dos efeitos de processos estruturados sobre os atores. Joganos no universo de regras e relaçóes sociais que delimitam os contornos das classes ou fraçóes de classe, demarcando espaços da luta política, e condicionando alternativas e recursos materiais ou simbólicos mobilizáveis pelos contendores. É uma linguagem indireta, mediada pela percepção dos atores, e que só pode ser analiticamente pensada se, rompendo com o voluntarismo, examinarmos as dimensões coercitivas e não intencionais das práticas sociais.

Conjugados, esses pressupostos embasam as análises feitas. Se o que buscamos é compreender a conversão de libertos e seus descendentes em assalariados participantes dos movimentos operários republicanos, não basta investigar as estruturas que delineiam o mercado de trabalho e as relações de produção, desprezando o exame das ações que tecem o entrechoque das forças em cada conjuntura. Tal estudo particulariza a "sociedade de mercado", decifra conexões relevantes e revela o significado de muitos conflitos, mas nada diz sobre suas dinâmicas específicas. Pela mesma razão, não basta reconstituir experiências, racionalidades e valores de indivíduos isolados, e projetá-los sobre os movimentos coletivos, descartando a análise do jogo relacional, estratégico e contingente que dá corpo aos conflitos. Análises desse tipo mencionam o político, mas não conseguem penetrá-lo. As situações conflitantes e os movimentos políticos não são simplesmente "dados"; necessitam ser metodicamente reconstituídos para serem convertidos em objetos de conhecimento.

Para demonstrar como os egressos do cativeiro contribuem para a formação do sindicalismo e marcam com sua bagagem sociocultural as organizações, é preciso romper essa barreira e penetrar no político. Há que buscar, portanto, a superação de tal dicotomia, combinando a abordagem histórico-estrutural com a estratégica. Nesse sentido, inserir o sindicato no mundo da produção, e o mundo da produção na teia de regras e relaçôes que o conformam e direcionam, é apenas o primeiro passo. Há que estudar também a cultura e as ações dos atores diretamente envolvidos na trama; acompanhar o aspecto dialógico da construção dos interesses coletivos; mostrar como a produção de significados é um aspecto decisivo das lutas, sem deixar de reconhecer que as iniciativas humanas têm em si mesmas a possibilidade 
de produzir realidades novas e inesperadas, pois contêm aspectos irredutíveis, não inteiramente constrangidos pelas estruturas.

Os elos que interligam o mundo dos valores e das vivências escravas aos movimentos operários do século XX estão na interseção de vários caminhos. É possível que ao longo da vida, na dura batalha pela alforria em meio a uma sociedade fortemente mercantil, muitos escravos tenham desenvolvido uma ideia negativa de liberdade, equacionando-a estritamente à autonomia pessoal e à ausência de constrangimentos. Esse fato contribuiria para a compreensão dos atos daqueles libertos que se tornam senhores de escravos, sem verem nisso contradição, mas pouco concorreria para o entendimento das ações dos "homens de cor" brasileiros que dão suor e sangue para a formação dos movimentos sindicais. Tal engajamento requer não só a quebra de antigos valores hierárquicos, como também uma concepção positiva de liberdade; liberdade pensada "como coisa de todos", equacionada à participação em agrupamentos orientados por valores coletivos, e não ao gozo tranquilo da independência individual. Para reflexão, acrescentamos, então, uma última proposição.

Mediando ações estão construções intencionais do real, mas no calor da luta pela afirmação de "horizontes de expectativas" possíveis e contraditórios, os atores - em seus valores, interesses e percepções - são sempre, de algum modo, transformados. Entre a liberdade negativa e a liberdade positiva não há quiçá barreiras intransponíveis, porém múltiplas sendas de interligação. Na conexão com o Oitocentos, compreender estas transformações e interligações é, por conseguinte, o nosso desafio maior.

\section{Notas}

${ }^{1}$ Entre outros, ver: FAUSTO, Boris. Trabalho urbano e conflito social, 1890-1920. São Paulo: DIFEL, 1979; MARAM, Sheldon, Anarquistas, imigrantes e o movimento operário brasileiro, 1890-1920. Rio de Janeiro: Paz e Terra, 1987; DE DECCA, M. Auxiliadora. A vida fora das fábricas. Rio de Janeiro: Paz e Terra, 1987; GITAHY,M. Lúcia. Ventos do mar: trabalhadores do porto, movimento operário e cultura urbana em Santos, 1889-1914. São Paulo: Ed. Unesp, Prefeitura de Santos, 1992; LOPREATO, Christina. O espirito da Revolta: a greve geral anarquista de 1917. São Paulo: Annablume, 2000; TOLEDO, Edilene. Travessias revolucionárias. Campinas: Ed. Unicamp, 2004.

${ }^{2}$ MARAM, Anarquistas, imigrantes, p. 22, 32; FAUSTO, Trabalho urbano, p. 125.

${ }^{3}$ MARAM, idem, p. 27; Fausto, idem, p. 36, 124-126; HAHNER, June. Poverty and politics: The urban poor in Brasil, 18701920. Albuquerque: Univ. of New Mexico Press, 1986, p. 213, 251-52; CHALHOUB, Sidney. Trabalho, lar \& botequim. $2^{a}$ ed. Campinas: Ed. Unicamp, 2001, p. 153-162.

${ }^{4}$ BATALHA, Cláudio. Le syndicalisme “amarelo" a Rio de Janeiro, 1906-1930. Tese de Doutorado. Paris: Université de Paris I, 1986; ZAIDAN, Michel. Pão e pau: política de governo e sindicalismo reformista no Rio de Janeiro, 1923-1925. Dissertação de Mestrado. Campinas: Unicamp, 1981.

${ }^{5}$ FERNANDES, Florestan. A integração do negro na sociedade de classes. São Paulo: Ática, 1978.

${ }^{6}$ LARA, Silvia. Blowing in the wind: E. P. Thompson e a experência negra no Brasil. Projeto História, n. 12 (1995); Escravidão, Cidadania e História do Trabalho no Brasil. Projeto História, n. 16 (1998).

${ }^{7}$ Para análises que enfatizam a participação de "homens de cor" no movimento operário organizado, Cf. CRUZ, Maria Cecília Velasco e. Tradições Negras na Formação de um Sindicato: Sociedade de Resistência dos Trabalhadores em Trapiche e Café, Rio de Janeiro, 1905-1930. Afro-Asia, n. 24 (2000), p. 243-290; em versão modificada, Puzzling Out Slave Origins in Rio de Janeiro Port Unionism: the 1906 strike and the SRTTC. In Hispanic American Historical Review, n. 82 (2006), p. 205-245; Solidariedade x Rivalidade: a formação do sindicalismo estivador brasileiro. História Unisinos, vol. 6, n. 6 (2002), p. 29-62; Cor, etnicidade e formação de classe no porto do Rio de Janeiro: a Sociedade de Resistência dos Trabalhadores em Trapiche e Café e o conflito de 1908, Revista USP, n. 68 (2005-2006), p. 188-209; ANDREWS, George. Negros e brancos em São Paulo (1888-1988). São Paulo: EDUSC, 1998; LONER, Beatriz. Construção de classe: operários de Pelotas e Rio Grande, 1888-1930. Pelotas: Ed. UFPel/Rede Unitrabalho, 2001; CASTELLUCCI, Aldrin. Trabalhadores, máquina política e eleiçôes na Primeira República. Tese de Doutorado em História. Salvador, UFBA, 2008.

${ }^{8}$ CARVALHO, Marcus. Liberdade. Rotinas e rupturas do escravismo no Recife, 1822-1850. Recife: Editora da UFPE, 2001, p. 213-214.

${ }^{9}$ Idem, p. 213.

${ }^{10}$ Ibidem, p. 215. Ver também CHALHOUB, Sidney. Visões da liberdade. São Paulo: Companhia das Letras, 1990.

${ }^{11}$ A Razão, 9-08-1918. Ênfases minhas. 
${ }^{12}$ Jornal do Brasil, 22-12-1906; Correio da Manhã, idem. Ênfases minhas.

${ }^{13}$ Centro de Comércio e Indústria do Rio de Janeiro, Relatório apresentado em Assembleia Geral de 17 de julho de 1918. Rio de Janeiro: Oficinas gráficas de A Noite, 1918, p. 214-215. Ênfases minhas.

${ }^{14}$ BERLIN, Isaiah. Dois Conceitos de Liberdade, In: Quatro ensaios sobre a liberdade. Brasília: Editora UNB, 1981.

${ }^{15}$ A Razão, 23-08-1918. Ênfases minhas.

${ }^{16}$ CRUZ. Tradiçōes negras. Op. cit.

${ }^{17}$ A utilização de mão de obra avulsa tal como definida por Beveridge - engajamentos curtos e seleção aleatória - é comum em todos os portos e está relacionada à variação cotidiana da demanda por trabalho. Na língua inglesa diz-se "casual work/ worker", que numa tradução literal seria "trabalho/trabalhador ocasional" ou "eventual". Preferimos usar "trabalho/trabalhador avulso", por serem estes os termos usados pelos trabalhadores nacionais e na legislação trabalhista brasileira. BEVERIDGE, William. Unemployment. A problem of industry. Londres: Longsmans, Green \& Co 1909.

${ }^{18}$ CRUZ. Tradiçôes Negras. Op. cit.

${ }^{19}$ Código de Posturas de 1838, In: Codigo de Posturas da Illustrissima Camara Municipal do Rio de Janeiro e Editais da mesma Camara. Rio de Janeiro: Eduardo \& Henrique Laemmert, 1870, p. 19.

${ }^{20}$ FARIA, Adhemar de. “Os transportes urbanos de café no Rio de Janeiro”. In: O Café. Rio de Janeiro: Departamento Nacional de Café, 1934, p. 845.

${ }^{21}$ Edital de 11-07-1853, In: Codigo de Posturas da Illustrissima Camara. p. 66-69.

${ }^{22}$ CHAGAS, João. De Bond, Lisboa, 1897, In: O Rio de Janeiro na literatura portuguesa. LISBOA, Jacinto (org.) Lisboa: Oficinas Gráficas Manuel A. Pacheco, LDA. 1965, p. 174. Ênfases minhas.

${ }^{23}$ LEITÃO, Joaquim. "Do civismo e da arte no Brasil, Lisboa”, 1900, In: idem, p. 199. Ênfases minhas.

${ }^{24}$ Relatório da Repartição dos Negócios da Justiça apresentado por Honório H. Carneiro Leão à Assembleia Geral Legislativa na Sessão Ordinária de 1833. Exemplar sem folha de rosto, publicado em 1833.

25 Idem.

${ }^{26}$ Codigo de Posturas da Illustrissima Camara, p. 18-40, 51-56, 66-69.

${ }_{27}$ TERRA, Paulo Cruz. Tudo que transporta e carrega é negro? Carregadores, cocheiros e carroceiros no Rio de Janeiro (18241870). Dissertação de Mestrado. Niterói, UFF, 2007 apud RIBEIRO, Gladys e TERRA, Paulo. "A Atuação dos imigrantes portugueses nos movimentos sociais como fonte de garantia e alargamento de direitos", no prelo.

${ }^{28}$ BARBOSA, Luiz. Assistencia publica e privada no Rio de Janeiro. Rio de Janeiro, Typographia do Anuario do Brasil, 1922; CRUZ, Maria Cecília Velasco e. Amarelo e negro: matizes do comportamento operário no Rio de Janeiro da Primeira República. Dissertação de Mestrado. Rio de Janeiro, IUPERJ, 1981.

${ }^{29}$ Boletim da Illustrissima Camara Municipal da Corte. Rio de Janeiro, Typographia. Imperial e Constitucional de J. Villeneuve \& C., 1887, p. 12-13.

${ }^{30}$ Relevante para a compreensão do mercado de trabalho livre, na Corte, seria o estudo da saga miserável dos engajados portugueses e o do uso das leis de locação de serviços. Temas pouco conhecidos, estão ainda à espera do seu historiador.

${ }^{31}$ NABUCO, Joaquim. Conferência no Teatro de Santa Isabel, In: Obras completas, vol. VII. São Paulo: Instituto Progresso Editorial, 1949, p. 256-257.

${ }^{32}$ NABUCO, Joaquim. “O eclipse do abolicionismo”. Idem, vol. XII, p. 252.

${ }^{33}$ Ver, entre outros, AZEVEDO, Celia Marinho de. Onda negra, medo branco. Rio de Janeiro: Paz e Terra, 1987; GEBARA, Ademir. O mercado de trabalho livre no Brasil. São Paulo: Brasiliense, 1986; LAMOUNIER, Maria Lúcia. Da escravidão ao trabalho livre. Campinas: Papirus, 1988; MACHADO, Maria Helena. O plano e o pânico. Rio de Janeiro: Ed. UFRJ/ São Paulo: EDUSP, 1994; CASTRO, Hebe Mattos de. Das cores do silêncio. Rio de Janeiro: Arquivo Nacional, 1995; XAVIER, Regina. A conquista da liberdade. Campinas, Centro de Memória da UNICAMP, 1996. Pela importância conferida à tutela no surgimento do trabalho assalariado na Europa e desnudamento da ideologia do mercado, cf. CASTEL, Robert. As metamorfoses da questão Social. Petrópolis: Vozes, 1998; e o clássico POLANYI, Karl. A grande transformação. Rio de Janeiro: Campus, 1980 (1944).

${ }^{34}$ APEB, Registro de correspondências expedidas/ Fundo polícia, maço 5840. Agradeço a Wlamira Albuquerque a cessão deste documento, e a Cândido da Costa e Silva as informaçôes sobre do autor da carta.

${ }^{35}$ Esse Regulamento (transcrito na íntegra) e o livro de matrículas foram analisados por REIS, João José. De olho no Canto: trabalho de rua na Bahia na véspera da Abolição. Afro-Ásia, nº 24 (2000), p. 199-242. Sobre os cantos soteropolitanos, ver também do mesmo autor, A greve negra de 1857 na Bahia. Revista USP, n. 18 (1993), p. 8-29, e COSTA, Ana Ribeiro da. Espaços Negros: “cantos" e "lojas” em Salvador no século XIX. Caderno CRH, Suplemento (1991), p. 18-34.

${ }^{36}$ REIS, De olho no canto, op. cit., p. 210. 
${ }^{37}$ Idem, p. 212, 216-218.

${ }^{38}$ Relatorio do Ministro e Secretario dos Negocios da Justiça Manuel de Souza Dantas, apresentado à Assemblea Geral Legislativa na primeira sessão da decima oitava Legislatura. Rio de Janeiro: Typ. Nacional, 1882, p. 195-196.

${ }^{39}$ Idem, p. 196.

${ }^{40}$ Ver GRAHAM, Sandra. Proteção e Obediência. São Paulo: Companhia das Letras, 1992.

${ }^{41}$ Consolidação das Leis e Posturas Municipaes do Distrito Federal, Primeira Parte, Rio de Janeiro: Officinas Typographicas de Paula Souza \& Comp., 1905, p. 147.

${ }^{42}$ AGCRJ, Ganhadores Livres, códices 44-1-27, 44-1-28 e 44-1-30; Africanos Livres ao Ganho, códice 39-1-30.

${ }^{43}$ IBGE (coleção digitalizada), Recenseamento do Brasil de 1872, Município Neutro, p. 61.

${ }^{44}$ Relatório de Cardoso de Castro, Chefe de Policia do Distrito Federal, anexo ao Relatorio apresentado ao Presidente da Republica dos Estados Unidos do Brasil pelo Dr. J. J. Seabra, Ministro da Justiça e Negocios Interiores. Rio de Janeiro: Imprensa Nacional, 1905. Parte da estatística não coincide com as cifras indicadas nos relatórios dos Ministros da Justiça. Entretanto, como os dois conjuntos de dados referem-se a gestôes com extensōes diversas, e como ambos indicam irregularidades de magnitude semelhante, as disparidades foram consideradas irrelevantes para o argumento.

45 SOARES, Luiz Carlos. Os escravos de ganho no Rio de Janeiro do Século XIX. Revista Brasileira de História, vol. 8, nº 16 (1988), p. 139.

${ }^{46}$ AGCRJ. Código de Posturas de 1889, exemplar truncado; Consolidação das Leis e Posturas Municipais, 1905, p. 396-97.

${ }^{47}$ Gazeta Operaria. Ano I, n ${ }^{\circ} 12,14-12-1902$.

${ }^{48}$ Gazeta Operaria. Ano II, n 16, 11-01-1903; Jornal do Brasil, 24-11-1906.

${ }^{49}$ Assistencia Publica e Privada, p. 626.

${ }^{50}$ CABRAL, A. do Valle. Guia do Viajante no Rio de Janeiro. Rio de Janeiro: G. Leuzinger \& Filhos, B. L. Garnier, e H. Laemmert \& C., 1884, p. 26-27.

${ }^{51}$ Representação contra a abolição imediata do elemento servil, janeiro de 1885, In: Relatorio da Junta Diretora da Associação Commercial da Praça da Bahia, 1886.

52 Documento transcrito, In: OLIVEIRA, Maria Inês Cortes de. O Liberto. O seu mundo e os outros. Dissertação de Mestrado em Ciências Sociais, UFBA, 1979.

${ }^{53}$ Agradeço a Aldrin Castellucci o acesso ao documento. Para uma análise do recôncavo nesse período, ver FRAGA FILHO, Walter. Encruzilhadas da liberdade. Campinas: Ed. da Unicamp, 2006.

${ }^{54}$ AGCRJ. Código de Posturas de 1889, p. 98-99.

55 Sindicato dos Arrumadores e do Comércio Armazenador do Rio de Janeiro. Documento manuscrito com informaçōes históricas sobre a fundação da Sociedade, redigido para ser apresentado à Comissão de Finanças em 1908.

${ }^{56}$ MARTINS, José de Souza. Subúrbio. São Paulo: Hucitec/São Caetano: Prefeitura de São Caetano do Sul, 1992, p. 179.

${ }^{57}$ Idem, p. 178. Ênfase de Martins.

${ }^{58}$ FRAGA FILHO. Encruzilhadas da liberdade, p. 16.

${ }^{59}$ Jornal do Brasil, "Queixas do Povo", 27-09-1903.

${ }^{60} \mathrm{Na}$ Barricada. Ano II, no 1, 1-01-1916. Arias de Castro era, na época, membro do Conselho da Resistência.

${ }^{61}$ Jornal do Brasil, 22-12-1906; Correio da Manhã, idem.

${ }^{62} \mathrm{O}$ art. 11, seção IV, do Código de Posturas de 1889 proíbe "dentro das casas ou chácaras, o brinquedo denominado batuque, com toques de tambor, cantorias e danças", e o 12 estabelece que "não são toleradas as casas chamadas zungús"; o art. 722 da Consolidação de 1905 proíbe "nas casas de bebidas, tavernas ou outros lugares públicos, ajuntamentos de pessoas com tocatas, danças ou vozeria”, prevendo multas e prisão. Código de Posturas, p. 49-50; Consolidação, p. 169.

${ }^{63}$ KOZERITZ, Carl Von. Imagens do Brasil. Belo Horizonte: Itatiaia/São Paulo: EDUSP, 1980, p. 31.

${ }^{64}$ Relatório de Cardoso de Castro, Chefe de Polícia do DF, anexo ao Relatorio apresentado ao Presidente da Republica dos Estados Unidos do Brasil pelo Dr. J. J. Seabra, Ministro da Justiça e Negócios Interiores. Rio de Janeiro, Imprensa Nacional, 1904. ${ }^{65}$ FOUCAULT, Michel. Nietzsche, a Genealogia e a História. In: Microfísica do Poder. Rio de Janeiro: Graal, 1984, p. 25-26.

${ }^{66}$ Demonstrar este fato não é tarefa simples. A apropriação e inversão das regras só se deixam ver em atos dispersos ao longo do tempo, e uma análise dessa magnitude ultrapassa os limites deste artigo. A título de exemplo, é possível dizer, entretanto, que as atas da Resistência e alguns depoimentos de operários idosos demonstram com segurança que a Resistência reproduz inicialmente a estrutura criada em Salvador pelo regulamento policial: turmas diversas e fixas de trabalhadores avulsos matriculados, cada qual monopolizadora dos serviços afetos a um determinado local geográfico de trabalho. Por outro lado, tal como na Bahia, no Rio o "capitão" se mantém como um trabalhador vitalício e diferenciado, só que enquadrado pela Sociedade de Resistência e não pelo Chefe de Polícia. 
${ }^{67}$ Não sem contradiçōes. Ao assumir o disciplinamento dos operários, o sindicato traz para sua dinâmica institucional os conflitos internos às turmas de trabalho.

${ }^{68}$ A Razão, 23-08-1918.

${ }^{69}$ FOUCAULT, op. cit., p. 28.

\section{RESUMO}

Este artigo tem como objetivo demonstrar por que, para se compreender a participação dos libertos e seus descendentes na formação do movimento operário da Primeira República, é preciso ir além dos estudos que privilegiam o agir humano (agency) e as experiências individuais, sem buscar inseri-las em análises estruturais do mercado de trabalho, das relações de produção e dos processos de trabalho. Para tanto, constrói-se o argumento a partir de uma análise substantiva, cujos fios condutores são a elucidação de "termos de época" e a discussão dos significados do conceito de liberdade implícitos nas falas dos patróes e operários em momentos de conflito aberto.

Palavras-chave: escravos ganhadores, ganhadores livres, trabalhadores do porto, movimento operário, liberdade.

\section{ABSTRACT}

This article intends to demonstrate why, in order to understand the freed-slaves and their descendants participation in the formation of First Republic labor movements, we must go beyond studies that characterize human agency mostly in terms of individual experiences without further trying to fit them into structural analyses of labor market, relations of production and labor processes. The argument is built by means of a concrete analysis carried through an explanation of certain nineteenth century ordinary language terms as well as by a discussion of the concept of freedom and its implicit meanings in speeches made both by employers and workers in times of open conflict. Keywords: slaves "ganhadores", free "ganhadores", port workers, labor movement, liberty. 